\title{
Prospects for the Northwestern Russian Forest Raw Material Harvesting during the Transition to a Market Economy
}

\author{
MATS NILSSON ${ }^{1}$ and ANDRIS KLEINHOF ${ }^{2}$
}

(Received 23 August 1999; accepted in revised form 29 November 2000)

\begin{abstract}
This paper analyzes the long-term prospects of profitably harvesting the forests in northwestern Russia in a sustainable manner, indicating the potential short- to medium-term competitiveness of the Russian forestry in both domestic and international markets. We have chosen a systemic approach (a modification of Porter's Diamond) to investigate the threats to and possibilities of the Russian forestry. This means that we consider not only factor conditions, but also demand conditions, the presence and status of related and supporting industries, firm strategy, structure, and rivalry, and the role of government in creating a competitive Russian forestry. Our analysis of the factor conditions prevailing in the mid to late 1990s indicates that the prospects for the Russian forestry could be very good. However, this potential will be realized only if substantial problems can be solved with regard to revising government policy, clarifying property rights, developing and maintaining the infrastructure, and achieving a stable and not too rapid increase in costs. Furthermore, we think that domestic demand is a weak link and that a revitalization of this demand is necessary.
\end{abstract}

Key words: competitiveness, forest, Porter's Diamond, Russia, transition

RÉSUMÉ. Cet article offre une analyse des perspectives à long terme d'une exploitation forestière rentable et durable des forêts du nord-ouest de la Russie, analyse qui souligne la compétitivité potentielle à court et à moyen terme de l'industrie forestière russe sur les marchés domestique comme international. On a choisi une approche systémique (une version du losange de Porter) pour étudier les éléments qui constituent une menace pour l'industrie forestière russe et ceux qui représentent des ouvertures. Ce qui signifie qu'on ne considère pas seulement les conditions des facteurs mais aussi les conditions de la demande, la présence et le statut des industries connexes et dérivées, la stratégie des entreprises de même que leur structure et leur rivalité, ainsi que le rôle du gouvernement dans la création d'une industrie forestière russe concurrentielle. Notre analyse des conditions des facteurs prédominantes du milieu à la fin des années 1990 révèle que les perspectives pour l'industrie forestière russe pourraient être très bonnes. Ce potentiel ne se concrétisera toutefois qu'après la résolution de problèmes majeurs visant la révision de la politique gouvernementale, la clarification des droits de propriété, le développement et le maintien de l'infrastructure, ainsi que la réalisation d'un accroissement stable et assez lent des coûts. On croit de plus que la demande nationale constitue un maillon fragile et qu'une revitalisation de cette demande s'impose.

Mots clés: compétitivité, forêt, losange de Porter, Russie, transition

Traduit pour la revue Arctic par Nésida Loyer.

\section{INTRODUCTION}

\section{Forest Resources in Russia}

The forests and forest industry of the Former Soviet Union (FSU) have long been one of the most important suppliers of wood raw materials in Europe. The ability (or inability) of the FSU to use these vast resources effectively could have an enormous impact on the forest raw material trade in northern Europe. The Russian share is about $94 \%$ of the FSU's total growing stock, or $96 \%$ of the allowable harvest in the FSU (Moscow Academy of Sciences of the USSR, 1991). In 1993, the FSU was the world's second-largest gross exporter (and largest net exporter) of roundwood (FAO, 1993). (We use "roundwood" as a common name for forest raw material intended for pulpwood or saw timber.) Total exports in 1993 amounted to $7215000 \mathrm{~m}^{3}$ solid volume. The world price of Russian roundwood is hard to find, but we can compare the prices paid for Russian softwood at the Swedish border to competitors' prices. These are not really prices, but rather the unit cost at the border: US $\$$ per $\mathrm{m}^{3}$, including cost, insurance and freight. For example, the 1993 price for Russian pulpwood was $\$ 34.10$, about $10 \%$ lower than the $\$ 37.30$ paid for German pulpwood (Exchange rate: $7.803 \mathrm{SEK} /$ \$US; Swedish Board of Forestry, 1996). Russian prices

\footnotetext{
${ }^{1}$ Division of Economics, Luleå University of Technology, SE-971 87 Luleå, Sweden; present address: Swedish Competition Authority, S 10335, Stockholm, Sweden; mats.nilsson@kkv.se

${ }^{2}$ All Russia Research Institute for Silviculture and Forestry Mechanization, Moscow State Forest University, 141200 Puschkino, Russia; kleinhof@mgul.ac.ru

(C) The Arctic Institute of North America
} 
FOREST HARVESTING IN NW RUSSIA • 175

seem very competitive, but the price difference also reflects some differences in quality (see, for example, Bergfors et al., 1989; R. Andersson, pers. comm. 1997).

The profound transformation of the country's political and economic systems that began in the late 1980s and early 1990s has created a number of uncertainties. For example, what are the viability and the role of the FSU's forest industry in the emerging market economy setting? In this paper, we define the term "forest industry" in a wider sense, to include the harvesting enterprises and the next level in the development chain, such as sawmills and fiberboard or pulp and paper plants. What we call "forest enterprises" are mainly concerned with harvesting operations.

The present study analyzes the prospects of profitably harvesting the forests in northwestern Russia in a sustainable manner over the long term and indicates the industry's potential competitiveness in the domestic and international markets in the 21 st century. The northwestern region includes the Republic of Karelia, the Republic of Komi, and the oblasts (provinces or subregions) of Archangelsk, Vologodsk, and Murmansk. Insofar as possible, given data availability, the analysis includes all these regions. Backman (1995) reports three main findings: First, the availability of new capital is crucial; second, total exports from Russia will decline unless the infrastructure is expanded and new harvesting technologies are used; and third, policies that will ensure high sustainable harvests over the long term need to be put into practice. Backman (1994, $1995,1996 a, b)$ has covered the physical availability of the forest resources in the FSU in some detail. We have added to his contributions a more detailed discussion of costs, markets, and the structure of forestry companies, as well as the impact of government policy (or, in some cases, lack thereof) on the forest enterprises, particularly those in northwestern Russia.

The northern economic region has played a leading role in the development of the Russian forest sector. In 1997, its share of Russian forestry industry output was about $35 \%$ for roundwood and more than $13 \%$ for saw timber. This region also accounted for almost half of the total paper production in the Russian Federation (Forest Complex of the Russian Federation, 1998).

The current social and economic crisis in Russia is an effect of the earlier administrative command system. Most of the industries in the FSU had already begun to lag behind those of developed countries in the early 1970s. One result of ignoring the requirements of a "normal" market economy was irrational decisions about where to locate large forest industry capacities for roundwood processing. For example, several enterprises were located in the Far East and Siberia. The transition to a market economy immediately revealed such flaws and "punished" badly located enterprises with high transportation and energy costs. We may also point out other flaws, such as inappropriate harvesting, ignoring economies of scale, and simply producing the wrong products.

\section{COMPETITIVENESS IN AN INTERNATIONAL PERSPECTIVE AND THE PORTER FRAMEWORK}

\section{Introduction}

There is a long history of efforts to explain competitiveness in international trade. The classical theory is that of comparative advantage (e.g., Jepma et al., 1996). That is, if a country is relatively well endowed with a resource such as labor (or, as in the Russian case, vast forests), this gives the country its comparative advantage. This theory predicts that a country will be competitive and produce in industries where it has a comparative advantage, recognizing that market forces will allocate a nation's resources to those industries where the resources are relatively most productive. The theory of comparative advantage, which is based on factors of production, has intuitive appeal, and national differences in factor costs have historically played a role in determining trade patterns in many industries.

Russian forests are among the largest in the world. Labor costs do not seem to be prohibitive. Thus, using the theory of comparative advantage, it would be easy to conclude that northwestern Russia is highly competitive in the international roundwood market because of its vast forest inventories and its relatively cheap labor. Still, exports of roundwood have decreased dramatically despite a collapsing domestic Russian market. We believe that the standard methods of analyzing potential competitiveness ignore several important issues. One issue that requires attention is the impact of the institutional setting within a country. The theory of comparative advantage implicitly assumes an efficient use of production factors, leaving little role for the effects of organizational structure and institutions on economic growth. Another overlooked issue is the impact of domestic demand. Even though we are analyzing a raw material, roundwood, customers are increasingly demanding high-quality products (freshness and correct harvesting and measurement methods are among the criteria). The domestic demand for high-quality roundwood puts pressure on the suppliers and encourages them to improve, thus making it easier to meet increasingly tougher international quality requirements. Finally, bringing in the issue of supporting and related industries would further enhance the analysis. If these industries are strong in an international perspective, they should strengthen competitiveness in the domestic market.

\section{The Porter Framework}

To investigate the threats and possibilities in Russian forestry, we have chosen a systemic approach first suggested by Porter (1990). The "resource-based theory" developed during the 1990s (Westgren, 1994) also fits well into the way we use the Porter framework. According to Porter, the answer to whether a particular industry in a country is competitive or not lies in four broad attributes of the country. These attributes, individually and as a 
system, constitute the "diamond" of national advantage, the playing field that each nation establishes and operates for its industries. These attributes, the determinants of competitiveness, are the following:

- Factor conditions: The nation's position in factors of production, such as labor and capital.

- Demand conditions: The nature of the domestic market.

- Related and supporting industries: The presence or absence of such industries and its impact upon competitiveness.

- Firm strategy, structure, and rivalry: The conditions in the nation governing how companies are created, organized, and managed, as well as the nature of domestic rivalry.

Included in the model is another attribute: chance. Chance influences the determinants, but is not, according to Porter, a determinant itself. Chance includes events like oil shocks and wars that change the conditions inside the diamond and put pressure on the determinants. An oil shock, for example, raises input costs, lowers demand, and creates a disadvantage in factor conditions.

Porter also considers government to be an attribute outside the diamond. He considers the government to be "part of the game" influencing the four determinants (e.g., through subsidies, education, and policies related to the financial markets) with its basic role of supporting innovation and upgrading. The government can act as a major buyer of goods, thereby influencing domestic demand. It can also use regulations and standards to influence quality or the production process. Substantial changes inside the diamond, that is, in the interaction between determinants or within a determinant, can also trigger actions from the government. Higher production costs, for example, can lead to a devaluation of the currency.

Strength in a determinant (e.g., being relatively well endowed with forests and skilled labor) means that this part of the diamond will strengthen international competitiveness. But because the diamond works as a system, a weak determinant could be enough to seriously impede competitiveness (e.g., if the structure of industry firms does not promote productivity and the upgrading of quality).

Porter's approach to competitiveness in certain industries has been used previously, for example, with respect to iron ore (Hellmer, 1997). Hellmer found that several aspects of the "diamond-analysis" were applicable to explain the survival of LKAB (a Swedish mining company) despite toughening international competition.

Some criticism of Porter's model is based on the view that an advanced domestic demand is crucial for success. Auerbach and Skott (1994) mention the example of the Japanese audio industry, which in the beginning was met by quite an unsophisticated domestic demand, yet has upgraded and is now a world leader. Further, they criticize the way Porter dismisses the notion that low prices on factors of production can lead to a long-term competitive advantage, mentioning South Korea's low wage strategy in the 1960s as one example. To this criticism, we would like to add that the lack of clear definitions of the determinants weakens the theory. Yet there has also been ample support for Porter's theory: Ergas (1984) identifies several of the factors that Porter incorporates in his diamond, and Kogut (1991) seems to agree with Porter almost completely.

\section{The Modified Diamond}

In this study, we use five rather than four determinants of competitive advantage to systematize the analysis: factor conditions; demand conditions; the presence and status of related and supporting industries; firm strategy, structure, and rivalry; and finally, the impact of the government on the industry. Van den Bosch and de Man (1994) criticize Porter for placing the government outside the diamond. Instead, they argue that this attribute could very well be inside the diamond, in that micro-economic policies aimed at specified industries through a product's life cycle could qualify the government as a fifth determinant. This criticism seems valid and it is crucial in our case to include the government's actions (and sometimes its inactivity) in the analysis of the Russian forestry. Government action is crucial to competitiveness in a transitional economy where the institutional setting is being created, i.e., the rules of the market are changing, thus changing the incentive structure of the participating actors. In Russia, the government impact on the forest industry may be direct, through legislation and fiscal policies, but it is obvious that it affects transactions by affecting the informal rules currently existing in the Russian business sphere. Further, the government still manages forests, or the old nomenklatura remains in power in the forest enterprises. Thus, our "Russian Forest Industry Diamond" will be analyzed using the model in Figure 1, in which the attributes interact and create what we define as a "competitive advantage."

\section{The Diamond and Russia}

Porter's framework has ordinarily been used for analysis of developed market economies, to mainly explain success stories (e.g., Porter, 1990). Here, it is applied to Russia and to a raw material supply industry.

Despite the shortcomings of the diamond framework, a viable analysis within it is possible. Such analysis will help put the endowment of factor conditions for the Russian forestry into perspective.

The first determinant of the diamond, factor conditions, deals mainly with investigating production costs. The second determinant focuses on domestic demand conditions, which are assumed to be more dynamic. Here the demand for quality is more important than quantity in the process of creating a global competitive advantage. For the forest enterprises to survive, we suggest that a critical 


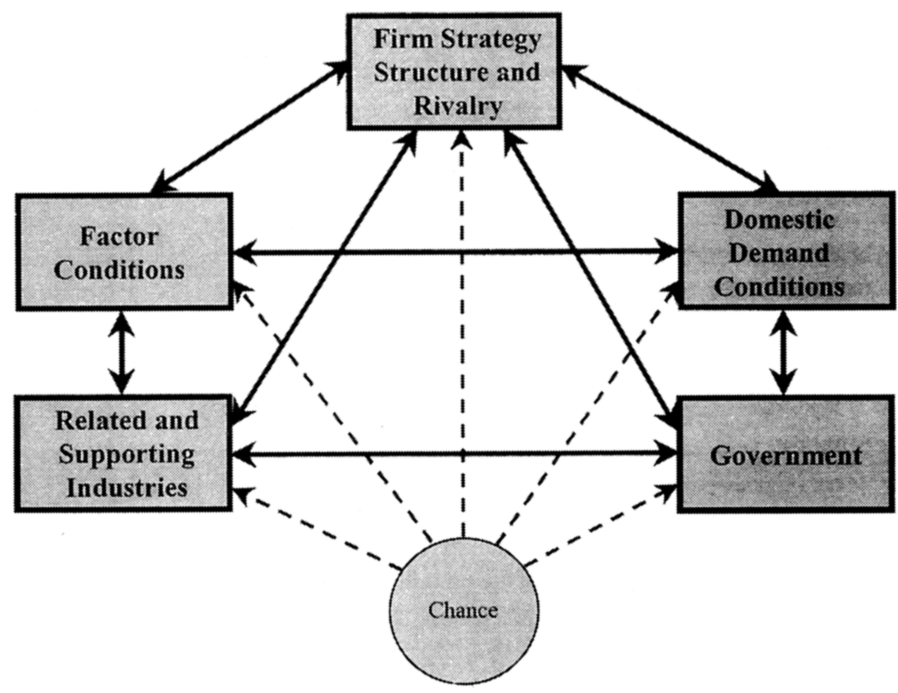

FIG. 1. The Porter Diamond modified for the Russian situation to include government as a fifth determinant.

mass of domestic demand is needed. Whereas Porter discusses the quality issues of demand, innovation, and upgrading of products, the demand for "low-quality" roundwood would help Russian forestry enterprises in our case (compare with the Japanese audio industry example).

The third determinant, related and supporting industries, emphasizes the importance of an internationally competitive supplier industry. In Russia, there are several aspects of this to consider. First is what Porter considers the synergy effects between vertically and horizontally related industries that may share ideas and cooperate to develop new technologies. In forestry, it is also important to explore the status of the related industries, because most capital equipment in the forest enterprises is Russian, and maintenance and repair are heavily dependent on the functioning of the firms in these related industries.

The fourth determinant summarizes the influence on competitiveness of firm strategy, organization, and management and domestic rivalry. This category can include, for example, the role of company goals (individuals' or investors') and ideology. Several Russian forestry enterprises have been privatized, often as joint stock companies. In practice, the old nomenklatura has often remained in power (e.g., Backman, 1996a) with the sector having the same employees and management.

Our fifth determinant, government, is important from two aspects. How is the government treating forests over time? And how is the government interacting with firms and regions? Our analysis follows van den Bosch and de Man (1994) and shifts the focus from macroeconomic issues to microeconomic issues.

Porter's and other similar studies were done in a dynamic setting, often considering the changes in several factors over time. What they could disregard, which we cannot, is that we are exploring an industry in a postCommunist market. This industry suffers in some sense from the remaining institutions and structure of the command economy and has not yet adapted to the new conditions of a market economy. What will be the future government policies and regulations in this industry is quite uncertain.

We assume that the ability to find a competitive position in roundwood trade in the short run and to maintain this position in the long run depends on the strength of the five determinants in the diamond, their interdependence, and their interaction with each other. The following analysis covers the short to intermediate run, with some extensions to the long-term possibilities of Russian forestry.

\section{APPROACHING THE ISSUE OF COMPETITIVENESS IN RUSSIAN FORESTRY}

\section{Factor Conditions and Endowments}

The most important competitive advantage for Russia is the availability of resources and skills. However, a significant portion of the Russian forestry resource is either physically or economically inaccessible.

In 1990, according to official figures, estimated stocks of standing timber (i.e., growing trees) were 815 million $\mathrm{m}^{3}$ in the Republic of Karelia (henceforth Karelia) and 201 million $\mathrm{m}^{3}$ in the oblast of Murmanskaya (henceforth Murmansk). In Karelia, this stock increased to 859 million $\mathrm{m}^{3}$ by 1995 , whereas in Murmansk the inventory remained unchanged. This inventory can be compared with the total 1990 inventory of neighboring areas such as Sweden (2471 million $\mathrm{m}^{3}$ ), Finland (1679 million $\mathrm{m}^{3}$ ), and Poland (1380 million $\mathrm{m}^{3}$ ) (Swedish Board of Forestry, 1996). Thus the potential impact of northwestern Russia's vast resources on the Nordic roundwood trade is quite large. Of course, the size of the inventory is unimportant if a significant part of the resource is physically or economically inaccessible.

In the northern region, a significant part of the forest resources is also of low quality. Such unproductive stands occupy $55 \%$ of the forested area in Murmansk, about 30\% in the republics of Komi and Archangelsk, and about 7\% in Karelia and Vologda. Large portions of the remaining forest resources (all the forests in Murmansk and those in the northern part of Komi and Archangelsk) are physically and economically inaccessible. The economic inaccessibility of the northern roundwood resources is mostly caused by the drastic economic changes, i.e., very high rises in energy prices and transport costs and obsolete equipment and machines. If the economic situation in Russia changes to a stable long-term equilibrium, with less volatility in input prices and lower interest rates that would make reinvestment possible, these regions could profitably harvest the forest's resources. Further, an improvement of the economic situation could also lead to more effective forest management, e.g., better forest reproduction methods. The transitional period from a command to a market economy 
TABLE 1. Actual harvest as a percentage of annual allowable harvest in the northern region of Russia, 1996.

\begin{tabular}{lcc}
\hline \hline Subregion & All Species & Coniferous \\
\hline Archangelsk & 0.37 & 0.41 \\
Vologodsk & 0.30 & 0.45 \\
Murmansk & 0.17 & 0.18 \\
Republic of Karelia & 0.60 & 0.62 \\
Republic of Komi & 0.18 & 0.21 \\
\hline \hline
\end{tabular}

Source: Russian Academy of Sciences, KEPS, 1996, Translu project.

has seen silvicultural practices decline in quality and intensity. For example, in the northern region the maintenance of coniferous plantations to the age of final harvesting is very low, only about $20-30 \%$ of the entire area. As a result, the share of economically inaccessible stands will increase.

Following the practice of others (e.g., Obersteiner, 1995), we use the annual allowable harvest as a guide for the potential harvest. Table 1 shows that the harvests are far below the allowable amounts. The figure for Murmansk may reflect the low commercial value of much of that region's forests. The comparatively high figure for the Republic of Karelia and the relatively low figure for Vologodsk are surprising. The government of the Republic of Komi has made futile attempts to support the republic's harvesting enterprises. The lack of capital usually means that programs like those discussed in Komi are never implemented.

The starting point for the cost analysis is the careful compilation of data on product volumes and costs undertaken by the Institute for Productive Forces and Natural Resources (KEPS) of the Russian Academy of Sciences, called the Translu Project. Official exchange rates are used throughout in converting the ruble figures into U.S. dollars. Although the ruble exchange rate was not determined in a free market, Russian authorities adjusted it during the period between 1990 and 1995, thus reflecting underlying economic conditions.

Costs in US\$ per $\mathrm{m}^{3}$ for four enterprises in Karelia and one in Murmansk are available. The costs cover roundwood harvesting and chip production, transported over land by truck or train. Table 2 shows that the absolute costs have gone down in three of the five cases, most dramatically in Murmansk. If these costs are correct, this region has been transformed into a very competitive producer of roundwood, compared to the other regions. The harvesting costs in northwestern Russia are equivalent to those in Germany (\$US 29.95 in 1990 and \$US 23.00 in 1995) and the Canadian West (\$US 19.00 in 1990 and \$US 22.00 in 1995, numbers kindly provided by H. Ekstrom, Wood Resources Inc., Seattle, Washington, pers. comm. 1997). A phenomenon of decreasing costs in northwestern Russia can be seen. This, of course, is in part a reflection of the problems with the exchange rate we are using. In 1990, the Soviet Government fixed the exchange rate of the ruble,
TABLE 2. Costs (in $\$$ US per $\mathrm{m}^{3}$ ) of roundwood and chip production in selected forest enterprises.

\begin{tabular}{lccccc}
\hline \hline \multirow{2}{*}{ Location } & \multicolumn{2}{c}{ Roundwood } & & \multicolumn{2}{c}{ Chips } \\
\cline { 2 - 3 } \cline { 5 - 6 } & 1990 & 1995 & & 1990 & 1995 \\
\hline Northwest, average & 24.82 & 23.74 & & 18.72 & 16.00 \\
Karelia, average & 23.75 & 23.74 & & 18.13 & 16.00 \\
$\quad$ Kem & 27.60 & 21.51 & & 19.88 & - \\
$\quad$ Kondopoga & 25.13 & 27.60 & & 18.38 & 16.44 \\
$\quad$ Pudozh & 20.38 & 19.96 & & 17.50 & 15.89 \\
$\quad$ Suojarvi & 19.88 & 24.44 & & 16.38 & 14.89 \\
Murmansk & 34.63 & 23.64 & & 26.25 & - \\
\hline \hline
\end{tabular}

Source: Russian Academy of Sciences, KEPS, 1996, Translu project.

which was overstated in comparison to its purchasing power. By contrast, the 1995 exchange rate may have undervalued the ruble in order to increase exports.

The economic crisis and the transition have led to an increase in specific input costs, such as energy and capital (see Table 3). The costs of the trees themselves (included in materials as the stumpage cost) are about $2-3 \%$ of the total costs, a cost that has historically been an administratively set cost, usually set to zero or some nominal amount. As can be seen in Table 3, the fuel cost share has almost doubled in most cases, and the materials share in some cases has more than doubled. Only in Murmansk has the share of wages gone up. There are some problems in interpreting the reported rises in other costs.

Care should be taken when using the above enterprise accounting data. First, the costs may be inflated to avoid tax. We suspect that this may be the case if the figure in the other costs column in Table 3 is higher than $15 \%$. Also, a significant part of the enterprises' harvest volume is sold in barter, thus in part avoiding taxes. (In practice, barter is a rather costly way of trading. Linz and Krueger [1998] provide a good analysis of the effects of barter on the restructuring of Russian enterprises.)

A very important factor in the extraction of roundwood from the Russian forests is the accessibility of the resource. Currently, the railway is using only part of its freight carrying capacity, a fact related to the sharp drop in both freight and passenger transportation from 1992 to 1996. Many railroad cars and locomotives are outdated, beyond or close to their life limit. The relatively new part of the railroad's capacity was sufficient in 1996 to accommodate current volumes, as well as the increased volume expected before the year 2000 (Russian Academy of Sciences, KEPS, Translu project, 1996). Furthermore, transport tariffs in this industry rose by $28 \%$ between 1995 and 1996. If unused capacity exists, the price should be lower. (Unconfirmed sources in 1998 denied that this had happened. Instead, prices had risen to prohibitively high levels.)

Despite the obvious advantage of trading in the export market (the risk of default is less and the payments are in hard currency), exports have gone down. Table 4 summarizes what has happened to the exported volume in the 
TABLE 3. Roundwood production cost structure, by area and enterprise and main cost categories, 1990 and 1995 (\% of total costs). Costs delivered at central yard.

\begin{tabular}{|c|c|c|c|c|c|c|c|c|c|c|}
\hline \multirow[t]{2}{*}{ Area/Enterprise } & \multicolumn{2}{|c|}{$\begin{array}{l}\text { Materials } \\
\% \text { of Total }\end{array}$} & \multicolumn{2}{|c|}{$\begin{array}{c}\text { Fuel } \\
\% \text { of Total }\end{array}$} & \multicolumn{2}{|c|}{$\begin{array}{c}\text { Wages } \\
\% \text { of Total }\end{array}$} & \multicolumn{2}{|c|}{$\begin{array}{c}\text { Depreciation } \\
\% \text { of Total } \\
\end{array}$} & \multicolumn{2}{|c|}{$\begin{array}{c}\text { Other Costs } \\
\% \text { of Total }\end{array}$} \\
\hline & 1990 & 1995 & 1990 & 1995 & 1990 & 1995 & 1990 & 1995 & 1990 & 1995 \\
\hline Karelia, average & 21.9 & 33.9 & 4.1 & 7.8 & 37.8 & 32.3 & 28.4 & 8.8 & 7.8 & 17.2 \\
\hline Kem & 14.3 & 32.1 & 4.9 & 8.0 & 33.0 & 35.1 & 36.6 & 13.7 & 11.2 & 11.1 \\
\hline Kondopoga & 19.2 & 29.8 & 3.1 & 7.3 & 42.2 & 31.3 & 26.4 & 12.0 & 9.1 & 19.6 \\
\hline Pudozh & 20.2 & 35.8 & 3.9 & 7.0 & 30.9 & 30.5 & 31.2 & 7.0 & 13.8 & 19.7 \\
\hline Suojarvi & 26.4 & 35.4 & 5.2 & 7.7 & 39.9 & 33.7 & 27.2 & 7.2 & 1.3 & 16.0 \\
\hline Murmansk, average & 24.8 & 23.1 & 7.8 & 15.4 & 39.5 & 41.9 & 30.8 & 9.6 & 6.4 & 10.0 \\
\hline
\end{tabular}

Source: Russian Academy of Sciences, KEPS, 1996, Translu project.

1990s. This decrease is quite puzzling, since domestic demand has all but vanished (see below). However, the rate of decrease of exports is much slower than the corresponding rate of decrease in roundwood harvests. As a consequence, the ratio of exports to total roundwood production has increased from $10.3 \%$ in 1990 to $21.3 \%$ in 1997. For chemical pulps, the corresponding figures are $35.8 \%$ in 1990 and $81.9 \%$ in 1997 (Burdin, 1998).

Although the main conclusion is that northwestern Russia is well endowed with forest resources and that the costs of harvesting seem internationally competitive, exports have still gone down. This suggests that the factor endowment theory provides only part of the answer to the question of Russia's competitiveness in forestry.

\section{Domestic Demand}

Domestic demand is important to the harvesting enterprise, since it will decide the mix of forest harvested and regenerated and also the type of harvesting done, i.e., thinnings (for quality purposes) or final harvests. It is also possible that technological breakthroughs in pulp or sawmills will lead to a change in the quality of raw material needed. This could help domestic raw material suppliers insofar as they are able to meet changing demand conditions. Domestic use, which in 1961 accounted for $98 \%$ of the harvested volume, slowly declined to $86 \%$ of the final harvest in the FSU in 1994 (FAOSTAT).

The domestic demand for roundwood in Russia has historically paid more attention to quantity than to quality issues. This causes problems in the current situation when the forest enterprises are seeking to export a rising share of production. Buyers of saw timber in Western Europe demand high-quality roundwood, but Russian firms often fail to understand these requirements. Although the knowhow is there, it has been proven somewhat difficult to meet the high demand for exports when domestic demand is still quite low. Eronen and Simula (1993) report that the Soviet paper industry produces more than 800 different types of paper, but that most of it is of rather inferior quality. The lack of test equipment and market orientation at the Russian pulp and paper mills severely restricts their competitiveness.
TABLE 4. Russian roundwood exports, 1990-97.

\begin{tabular}{cccc}
\hline \hline Year & Volume $\left(1000 \mathrm{~m}^{3}\right)$ & Value $(\$ U S)$ & Average Price $\left(\$ \mathrm{US} / \mathrm{m}^{3}\right)$ \\
\hline 1990 & 31400 & 1720000 & 54.80 \\
1995 & 18400 & 1065000 & 57.80 \\
1996 & 15914 & 945400 & 59.00 \\
1997 & 17699 & 1016900 & 57.00 \\
\hline \hline
\end{tabular}

Source: Kozhukov (1998).

Table 5 summarizes the production capacities and production volume for some of the larger enterprises in the northwestern part of Russia. Although these are aggregated data, they give a general picture of the situation in the late 1990s. The decline in capacity utilization is dramatic. In 1996 the Republic of Komi and the Archangelskaya oblast, using only $50-75 \%$ of their total capacity in 1996, were still using far more of the existing capacity than Leningradskaya oblast, Vologodskaya oblast, and the republic of Karelia. For the Russian forestry sector as a whole, the capacity utilization figures are as follows: fiberboard $43 \%$, particle board $35 \%$, plywood $50 \%$, pulp $38 \%$, paper $49 \%$, and paper board 29\% (Moiseev et al., 1997). Some of the largest pulp mills operated for only one to six months in 1997. In the short run (and possibly in the long run), the heavy drop in capacity utilization in the forest industry, ceteris paribus, should mean that more roundwood is available for exports. However, in the short run, the same factors that caused the drop in the production of pulp and lumber (such as an insufficient monetary system, missing markets, and insufficient domestic demand) also caused a drop in roundwood production.

One of the more obvious explanations of the demand implosion is the rate of increase in input prices. From 1995 to 1996 , the prices of roundwood rose by $12 \%$. This was quite small compared to price increases for electricity (35\%) and oil (40\%) in the same period (Moiseev et al., 1997). If these relative changes correctly reflect the longterm equilibrium (or at least the direction), then more intensive use of roundwood, versus energy, is expected. However, in many cases these rising input costs have meant negative profits; the forest sector as a whole is in debt (Moiseev et al., 1997). 
TABLE 5. Production of forest products in some northwestern Russian enterprises, 1996.

\begin{tabular}{llccc}
\hline \hline Region & Product & Production Capacity & Production Volume & Capacity Utilization \\
\hline Republic of Karelia & wood pulp & 127.5 & 40.9 & 0.32 \\
& paper & 995 & 551.1 & 0.55 \\
& sawn wood & 1098 & 270.4 & 0.25 \\
Republic of Komi & wood pulp & 345 & 312 & 0.61 \\
& paper & 468.5 & 147 & 0.67 \\
Archangelskaya oblast & sawn wood & 200 & 1021.3 & 0.68 \\
& wood pulp & 1503.4 & 541.5 & 0 \\
Voper & 1038.3 & 26.5 & 0.52 \\
& sawn wood & 0 & 28.2 & 0.32 \\
Lood pulp & 106.8 & 30.1 & 0.39 \\
& paper & 109.4 & 180.8 & 0.34 \\
& sawn wood & 200 & 180.5 & 0.30 \\
& wood pulp & 599.5 & 0 & 0.40 \\
\hline
\end{tabular}

Source: Russian Academy of Sciences, KEPS, 1996, Translu project.

As a result of the economic crisis that Russia has suffered, valuable infrastructure may be lost and forest enterprises may disappear for lack of domestic demand. We suggest that smaller quantities be exported; the exported volumes add important profits to the forest enterprises but are not in many cases the bulk. The demand for Russian roundwood abroad is limited in volume, to some extent because of quality concerns. The remaining companies of the Russian forestry sector do not have equipment that is modern enough to handle the requirements of the export markets. Therefore, an implosion of domestic demand could lead to a distinct decrease in exported volumes, such as is seen in Table 4. The capital requirements are lower for harvesting than for processing (e.g., paper or sawmills). In the medium to long run, this fact makes harvesting operations less sensitive than processing industries to ongoing changes.

One interesting question: Will domestic demand grow before the forest industry is dead? As of the end of 1998, the domestic demand for quality wood is still declining, reflecting in part the declining purchasing power of Russians. This is the crucial issue for one of our conclusions: that there may exist a necessary critical mass of domestic demand that makes it possible for the forest industry to survive.

One solution to the problems of low know-how and worn-out capital stock in the Russian forestry processing industry would be foreign direct investment (FDI). According to the State Committee of Statistics, foreign investments in all Russian industries in 1995 were \$US 1.2 billion, or roughly $3 \%$ of total investment (foreign and domestic). (In 1994, the corresponding figures were \$US 1.05 billion, of which \$US 549 million was direct investment.) The preferred objects of FDI are food (24\%), fuel and energy (22\%), and forest and forest products (13\%).

Unfortunately, there are several reports of failures of FDI in Russia. Backman (1996a) describes the joint venture in Russia of Weyerhaeuser, an American company. Tak (1994) and van Fossen (1995) have somewhat different opinions on how to describe the operations in Russia of
Hyundai (a Korean company), but both report them as a failure. Finally, Nilsson and Söderholm (2000) briefly describe the costly project of ASSIDomän (a Swedish company) in Russia, as well as the importance of functioning institutions to attract FDI. Further, Myllynen (1996:111) reports on Finnish firms active in Russia:

Many problems face Finnish timber harvesting contractors. The working conditions are different due to the inadequacy of the infrastructure... Decaying trees should be left in the forest when complying with the Finnish directives, but in Russia the harvester will be penalized for doing so. As a result, timber extraction work is technically more complicated in Russia.

In Western Europe and North America, there has been pressure for all silvicultural activities and manufacturing to be environmentally friendly. This has only recently become an issue in Russia. Thus, Russian manufacturers of pulp, paper, and paperboard do not meet reasonable environmental standards. Further, a significant part of this branch of the forest industry has an obsolete capital stock (40-50 years old). In the case of fiberboard production, most of the equipment was imported. As the current lack of funds available to Russian firms makes it impossible to re-invest, or to even buy spare parts, capacity in that industry is slowly decreasing.

The core conclusions of this section are that the implosion of domestic demand for forest products may be devastating for forest enterprises. Exports could be one remedy to this problem, but the low quality of Russian products makes this unlikely. Foreign direct investment could also help, but since FDI has been more hindered than accommodated up until the late 1990s, it has not proven to be a possible solution. Therefore, the domestic demand for roundwood is weak in two senses. First, it does not raise the quality of production, as suggested by the Porter model. Second, the demand is small because of the general implosion of the Russian economy. 


\section{Related Industries}

The national presence of related competitive industries often leads to an advantage in keeping a competitive position. One example of this is the very competitive manufacturers of forest machinery associated with the Swedish and Finnish forest industries. Local manufacture of machinery has helped keep forestry productivity high, thereby keeping the costs of harvesting in the Nordic countries competitive. An example is the technological development of harvesters or skidders adapted to local conditions. One of Porter's (1990) stronger findings in his study of competitive advantage was that competitive industries were often associated with specialized research institutes or university departments. It is a well-known fact that the financial problems of the Russian state have had a devastating impact on Russian universities.

Manufacturers of forest equipment in Russia produce machinery such as chain saws, skidders, harvesters, and pulp boilers. However, Russia is not equipped to make certain equipment for the next step in the processing chain, such as machinery for the production of veneer sheets, structural composite goods, and various kinds of highquality paper and paperboard. Many of the equipment manufacturers that do exist should still be considered monopolies (i.e., they are the only manufacturers within the Russian Federation, and few foreign firms have chosen to enter the Russian market). Many enterprises are forced to borrow money at rates as high as $30-50 \%$. (The high interest rates reflect, of course, the high demand for credit and high risk of default, as well as factors like inflationary expectations.)

Only part of the existing forest equipment industry can be considered as state of the art. Moiseev et al. (1997) estimates that about $20 \%$ of the products made are comparable to products assembled outside Russia. This situation differs from branch to branch.

In the logging equipment industry, the prices for domestic equipment are often far below those of foreign (e.g., Finnish or Canadian) competitors. At the same time, Russian equipment (for logging as well as woodworking) is inferior regarding productivity, labor working conditions, and safety. Moreover, the relatively lower costs of domestic machinery are largely based on low-level wages. In the long run, substantial increases in productivity are needed to keep the industry competitive when facing an expected increase in labor costs.

The educational level and skills of the workers in the logging industry are good (one of the Swedish companies actively logging in Russia confirmed this; K. Boström, pers. comm. 1997). But the sector is losing forestry scientists because of missing payments to universities and research institutes. For example, research on pulp and paper has all but vanished. In the early 1990s, the former Soviet states, including Russia, were cooperating on research concerning silvicultural and logging equipment. However, the termination of this cooperation in the general mayhem may result in the loss of a potential domestic market for forest machinery. Only a small share of the few remaining professors and lecturers from the forestry institutes and universities are currently engaged in any research.

The related and supporting industries, as Porter defines them, exist in Russian forestry; however, we noticed several problems upon studying these industries. First, there exists in several cases an imperfect market structure with monopoly situations. Second, these industries, like most industries, were hard hit when costs rose to meet the demands of the "new" market situation. Until they make the necessary transformations in production and business planning, they will remain a weak part of our Russian forest industry diamond. Finally, only about $20 \%$ of the industry produces state-of-the-art products.

\section{Firm Structure and Rivalry}

This determinant of Porter's diamond includes the context in which business firms are created, organized, and managed. This context is important in the Russian case, since the forest enterprises had not, as of late 1998, found a satisfactory structure of ownership and organization. The change in ownership structure has not led to the rise in efficiency and productivity that is so badly needed. This failure may be an effect of the insiders' domination, in that no real change of management has occurred. We cannot report an exact figure, but in our opinion the $48 \%$ of insider-dominated firms reported in Earle and Estrin (1996) seems to be a lower bound for the forest industry. Quite the contrary of higher effectiveness has occurred: between 1994 and 1997, the share of unprofitable enterprises in the forest industry rose from $45.5 \%$ to $84.2 \%$ (Russian Statistics Yearbook, 1998).

To quote Stiglitz (1994:136), "More important in many cases than changing the 'ownership' is changing the market structure-subjecting these enterprises to competition." This has hardly happened in the Russian forestry industry. Furthermore, the existing bankruptcy law has not been enforced, and many enterprises have increasingly huge debts. Seemingly, with the current owners there is no future. In the northwestern region, the share of unprofitable enterprises ranged from $70.4 \%$ in Vologodsk to $89.7 \%$ in Komi (Russian Statistics Yearbook, 1998). Still, these companies do not go bankrupt.

A common theme of the transition literature is that successful restructuring of firms is necessary to transform from a planned to a market economy (Linz and Krueger, 1998). It seems that in many cases Russian forestry enterprises have adopted a defensive restructuring mode: that is, they seek to "change as little as possible while retaining insider control" (Ash and Hare, 1994:633).

In general, the forest enterprises have not adapted to the new economy, in that they have not learned how to act in the marketplace, or how to understand and adapt to new market conditions. In these areas, they are still in the learning stages, although some firms in some industries are beginning to shift their attention from short-term 
actions to formulating strategies for long-term viability (Clark and Baglione, 1998). For example, the stock of ownership shares was in many cases sold at prices a thousand times below the value of possible production.

Russian forestry enterprises have developed a sense of orientation towards costs, but not towards markets. Many firms rely on their ability to respond to the market by reducing costs, but do little to create a market or change their output (for a good example, see Clark and Baglione, 1998). Tackling the severe shortage of financial capital is usually seen as beyond the capabilities of the individual enterprise.

It is hard to conceive of a viable Russian low-cost strategy. To stay competitive in the long run, Russian forestry firms must either accommodate foreign leases and harvesting crews or increase the quality of their output. These enterprises need to make quite an effort in order to improve their "products."

Before 1992, international trade in forest products was highly centralized and carried out by specialized foreign trade organizations. Efforts to liberalize trade policies began in 1992, when the ruble was made convertible to hard currencies at a constant exchange rate. Since that time, the role of the centralized organizations has been reduced, and some of them have been privatized or abolished. Enterprise-to-enterprise trade is now allowed, and the former export taxes and export quotas have been phased out (World Bank, 1997).

One of the more serious problems of the Russian international trade policy is the lack of stability. There is no guarantee that the current customs tariffs, as well as other rules, will remain unchanged. In the late 1990s, many small exporters characterized the market. Since most of them had neither the knowledge of how international markets function nor information on price trends in the foreign markets, the export prices from different regions might vary substantially. In December 1998, for example, the price per cubic meter of birch veneer logs varied between \$25 and \$50 U.S. (Russian Statistics Yearbook, 1998). This ignorance of the quality requirements for foreign markets and of changes in prices and trends may be one explanation of why Russian prices remain substantially lower than those of competitors.

The lack of competition in many industries prolongs the time it will take for Russian companies to become internationally competitive. Further, there is some indication that firms concentrate too much on cutting production costs, and forget that they need to sell something that is in demand. We have found another weak determinant in our Russian "diamond."

\section{Government}

The Forest Code adopted by the state Duma in January 1997 (World Bank, 1997) can be considered a new stage in forest legislation. Unfortunately, in several important aspects it is out of line with the current social, economical, and environmental way of thinking.
The fundamental issues of land and forest ownership and management responsibilities are difficult to address until appropriate land legislation is implemented. However, the current lack of discussion concerning these important issues in the new code has left a lacuna that will add to the already existing confusion. The Russian constitution provides for the possibility of various forms of ownership (private, state, municipal, or other) of natural resources, including land and forests. Moreover, some regions in the Russian Federation, e.g., the Republic of Tatarstan and the Saratov Region, have declared some land as privately owned. The current legislation of many republics and regions (krai, oblasts) proposes that all stateowned forestland should be transferred to them. Contrarily, the Forest Code proposes that all state forests remain under federal ownership (article 19) and allows only a partial transfer of the state forest to the republics. Moreover, there is an imbalance between ownership rights and responsibilities of the Russian Federation and those of the republics and regions. Although the Russian Federation owns the forest, the republics and regions are responsible for forest resource use, protection, and regeneration.

Although the Forest Code declares that a fundamental requirement of the forest managers is to use the forests in a sustainable manner over the long run, it fails to provide legal or economic mechanisms for implementing such policies. The Forest Code is generally of a regulatory nature, lacking the incentives for increasing the effectiveness of forest resource use and reproduction.

Another important way in which government influences industry is through the currency exchange rate. In the long run, the exchange rate should convert to a level that neither helps nor hinders Russian exporting industries. What should matter is the relative advantage of the different industries (even widely interpreted in the "Porter-context"). The argument can be made that for a transition economy, which is presumably out of equilibrium, exchange rates may profoundly distort the economy. That is, high exchange rates increase costs for enterprises dependent on foreign material, making it difficult for them to reach an equilibrium point. On the other hand, in our case, high exchange rates to some extent protect the industry from foreign competition, making it easier for the enterprise to keep or expand its domestic market shares. The outcome is, therefore, ambiguous. Hence, we follow Wibe (1987) and leave this issue.

According to the office of the Russian procuratorgeneral (quoted on TV-News, Moscow, 27 December 1998), about half of the commercial banks, $40 \%$ of the state-owned companies, and $60 \%$ of private companies are under the control of criminal elements (organized crime). This informal controlling element may hamper the government, limiting its ability to implement policies.

To summarize, the role of the government is extremely important in a transitional economy, yet in some cases we see an appalling lack of policy. The institutional setting of the old Communist system-with gifts to administrators 
TABLE 6. Russian forest in a diamond context.

\begin{tabular}{|c|c|c|c|c|}
\hline Part of the Diamond & Good & Okay & $\mathrm{Bad}$ & Comment \\
\hline Factor Conditions and endowment & & $\mathrm{X}$ & & \\
\hline natural conditions & $\mathrm{X}$ & & & Large inventory \\
\hline infrastructure & & $\mathrm{X}$ & & Good railway network, but some doubts of its maintenance \\
\hline know-how & & $\mathrm{X}$ & & \\
\hline Demand & & & $\mathrm{X}$ & Quality problems, lack of critical mass domestically \\
\hline Foreign direct investment & & & $\mathrm{X}$ & Not good compared to other transitional economies \\
\hline Related and supporting industries & & $?^{1}$ & & Monopolies, low productivity and fairly low quality \\
\hline Firm strategy, structure and rivalry & & & $\mathrm{X}$ & Few changes and lack of renewal of management \\
\hline Government & & & $\mathrm{X}$ & Unstable, at which level should decisions be taken? \\
\hline legal setting & & & $\mathrm{X}$ & Widespread corruption, inappropriate taxation, unclear forest code \\
\hline property rights & & & ? & Unclear, discussion between regional and federal level \\
\hline
\end{tabular}

${ }^{1}$ The question mark denotes that the position in the table is unclear. We need more information to make a more clear-cut statement.

and widespread corruption-remains. We suggest that government is as important a determinant as the factor conditions in the Russian case. Its weakness may unfortunately counterbalance the strength of the resource factor conditions prevailing in Russia.

\section{DISCUSSION}

The survival and well-being of the Russian forestry industry will ultimately depend on its competitiveness in relation to other roundwood suppliers in the international market. Competitiveness, in turn, is dependent on several factors. Prospects for the Russian forestry could be very good, but only if substantial problems are resolved in regard to government policy, clarification of property rights, development and maintenance of the infrastructure, and a steady and not too rapid increase in costs. For the Russian forestry to regain its earlier production and establish itself as the leading supplier of forest raw materials in northern Europe, the domestic demand, considered a weak link, must be revitalized.

Table 6, summarizing the judgements and opinions of this paper, gives a rather dark picture of the likely nearterm competitiveness of the Russian forests. The only real strengths, in the resource factor conditions and resource endowment, are clearly not enough to make the Russian forestry competitive. If the other determinants of this system are not strengthened, the industry could, at least in the near to medium run, produce roundwood at volumes far below what would be sustainable in the long run.

An important factor in the manufacture of high-quality pulp and lumber is the freshness of the raw material, which requires efficiency from the moment the wood is harvested to its arrival at the factory gate. This means that the education of the personnel involved and the import of know-how from Western economies are crucial factors. The prospects for such transfers are good; however, the two critical deterrents to this development are the bad investment climate and the unstable institutional setting.

Several important changes are evident in the forestry sector. We could be seeing a return to stronger central planning if, for example, the central authorities should regain power over forestry exports. The results of such a return would depend on other factors, such as property rights. Assuming clear property rights and a policy of sustainable harvest, central planning could mean a less effective use of the Russian forest resource than would be possible in a free market. But if property rights were to remain weak and unclear, then stronger central planning could lead to overuse of the forests, which Pöyry (1988) claims has already occurred to some extent in Canada. Another result might be the redirection or termination of foreign direct investment. We agree with Backman (1996a) that the influx of fresh capital is crucial for the forest enterprises at this stage and that the Russian Duma should regard foreign investment as an issue of utmost importance.

The development of renewed domestic demand for forest raw material is of great importance. The wood products and pulp industry is suffering from some quality problems. Furthermore, in a recent study, Linz and Krueger (1998) found that in their sample of wood, forestry and pulp and paper firms (1992-95) the labor productivity has gone down in the worst case by $59.6 \%$ and in the best case by "only" $11.6 \%$.

Most of the forest raw material needs to be transported long distances, and the Communist practice of heavily subsidizing bulk transports has effectively ceased. The heavy increase in transport tariffs in 1995-96 should be seen as a warning.

To clarify the current situation and to identify long-term possibilities for the Russian forest industry, further research is needed on all this issues.

\section{ACKNOWLEDGEMENTS}

We thank Stefan Hellmer, two anonymous reviewers, and the editor and copy editor of Arctic for their assistance in improving the manuscript. M. Nilsson gratefully acknowledges support from the Jacob Wallenbergs/Lars-Eric Thunholm Foundation. 


\section{REFERENCES}

ASH, T., and HARE, P. 1994. Privatization in the Russian Federation: Changing enterprise behavior in the transition period. Cambridge Journal of Economics 18(6):619-634.

AUERBACH, P., and SKOTT, P. 1994. Michael Porter's inquiry into the nature and causes of the wealth of nations - the challenge to academic economics. Memo 1994-10. Unpubl. report available from the Department of Economics, University of Aarhus, 8000 Aarhus, Denmark.

BACKMAN, C.A. 1994. The Russian forest resource physical accessibility by economic region. Working Paper 94-126. Laxenburg, Austria: International Institute for Applied Systems Analysis.

1995. The Russian forest sector: Production, consumption, and export prospects. Post-Soviet Geography and Economics 36(5):310-322.

. 1996a. The Russian sector: Opportunities and challenges. Working Paper-96-53. Laxenburg, Austria: International Institute for Applied Systems Analysis.

. 1996b. The Russian forest sector: Prospects for trade with the former Soviet republics. Post-Soviet Geography and Economics 37(1):16-59.

BERGFORS, U., BERGMAN, M., and HULTKRANTZ, L. 1989. The competition in the Swedish roundwood market (In Swedish). Report No. 76. Umeå: Department of Forest Economics, Swedish University of Agricultural Science.

BURDIN, N., ed. 1998. Forest Economic Herald No 3. (in Russian). Available at All Russia Research Institute for Silviculture and Forestry Mechanization (VNIILM), Moscow State Forest University, 141200 Puschkino, Russia.

CLARK, C.L., and BAGLIONE, L.A. 1998. Interpreting firms' behavior in Russia's metallurgy industry. Journal of Economic Issues 42(4):925-963.

EARLE, J.S., and ESTRIN, S. 1996. Privatization versus competition: Changing enterprise behavior in Russia. Working Paper 96-049. Laxenburg, Austria: International Institute for Applied Systems Analysis.

ERGAS, H. 1984. Why do some countries innovate more than others? CEPS Report No. 5. Brussels: The Centre for European Policy Studies.

ERONEN, J., and SIMULA, M. 1993. Russia and other ex-Soviet republics' future paper markets. Paper presented at the Prima Conference, 12-14 May 1993, Helsinki.

FAO (FOOD AND AGRICULTURE ORGANIZATION). 1993. FAO yearbook of forest products. Rome: FAO.

FOREST COMPLEX OF THE RUSSIAN FEDERATION. 1998. Moscow. Report from NIPEI Lesprom. (In Russian). Available at All Russia Research Institute for Silviculture and Forestry Mechanization (VNIILM), Moscow State Forest University, 141200 Puschkino, Russia.

HELLMER, S. 1997. Competitive strength in iron ore production. Doctoral Thesis, Luleå University of Technology.

JEPMA, C.J., JAGER, H., and KAMPHUIS, E. 1996. Introduction to international economics. London: Longman.

KOGUT, B. 1991. Country capabilities and the permeability of borders. Strategic Management Journal 12:33-47.
KOZHUKOV, N.I. 1998. Forest sector of Russian economy on the verge of the third millennium (In Russian). Moscow: VNIILM.

LINZ, S.J., and KRUEGER, G. 1998. Enterprise re-structuring in Russia's transition economy: Formal and informal mechanisms. Comparative Economic Studies 40(2):5-52.

MOISEEV, N.A., KOZHUKOV, N.I., and KLEINHOF, A.E., eds. 1997. The elaboration of complex programs for sustainable development of forest sector in transition to the market economy (In Russian). Research report available at All Russia Research Institute for Silviculture and Forestry Mechanization (VNIILM), Moscow State Forest University, 141200 Puschkino, Russia.

MOSCOW ACADEMY OF SCIENCES OF THE USSR. 1991.

The forecast of forest resource use and reproduction in the USSR to the year 2010. Research report available from All Russia Research Institute for Silviculture and Forestry Mechanization, Moscow State Forest University, 141200 Puschkino, Russia.

MYLLYNEN, A-L. 1996. On the ecological and economic impacts of wood harvesting and trade in north-west Russia. European Forest Institute, Joensuu: Finland.

NILSSON, M., and SÖDERHOLM, P. 2000. Foreign direct investment and institutional obstacles: The case of Russian forestry. Unpubl. ms. Available at the Division of Economics, Luleå University of Technology, Division of Economics, 97187 Luleå, Sweden.

OBERSTEINER, M. 1995. Status and structure of the forest industry in Siberia. Working Paper WP-95-30. Laxenburg, Austria: International Institute for Applied Systems Analysis.

PORTER, M.E. 1990. The competitive advantage of nations. London: Macmillan Press.

PÖYRY, J. 1988. Demand, production, restrictions and policies: An economic view of the role and possibilities for agriculture and forestry in Europe, focused on the Scandinavian countries. Skogs och Lantbruksakademisk Tidskrift. Supplement. 21:57-71.

RUSSIAN STATISTICS YEARBOOK. 1998. The Russian statistics yearbook for 1997. Moscow: Goskomstat.

STIGLITZ, J.E. 1994. Whither socialism? The Wicksell Lectures, Cambridge and London: MIT Press.

SWEDISH BOARD OF FORESTRY. 1996. Swedish yearbook of forestry statistics. Jonkoping, Sweden.

TAK, K-I. 1994. Foreign investment in the forest sector in the Russian Far East and potential market integration with NorthEast Asia. Working paper WP-94-92. Laxenburg, Austria: International Institute for Applied Systems Analysis.

VAN DEN BOSCH, A.J., and DEMAN, A.-P. 1994. Government's impact on the business environment and strategic management. Journal of General Management 19:50-59.

VAN FOSSEN, C. 1995. The evolution of a comprehensive environmental strategy in the Russian Federation. Wisconsin International Law Journal 13(2):531-536.

WESTGREN, R.E. 1994. The microeconomics of competitiveness: Using a resource-based model of firm strategy. Research report, Guelph, Ontario: George Morris Centre.

WIBE, S. 1987. The long run competitiveness in the Swedish forest industry (In Swedish). Report 72. Umeå: Department of Forest Economics, Swedish University of Agricultural Science.

WORLD BANK. 1997. Russia. Forest policy during transition. Washington, D.C: The World Bank. 